\title{
CNC VEZÉRELT PROTOTÍPUSGYÁRTÓ BERENDEZÉS TERVEZÉSE
}

\author{
Kugler Gergely \\ hallgató, Miskolci Egyetem \\ Gép- és Terméktervezési Intézet \\ 3515 Miskolc, Miskolc-Egyetemváros, e-mail: kugigergo@gmail.com \\ Bihari Zoltán \\ egyetemi docens, Miskolci Egyetem \\ Gép- és Terméktervezési Intézet \\ 3515 Miskolc, Miskolc-Egyetemváros,e-mail: machbz@uni-miskolc.hu
}

\begin{abstract}
Absztrakt
Ez a cikk a prototípusgyártó eszközök egy konkrét fajtájáról annak kialakulásáról, felépitéséröl, valamint müködéséröl szól. Ezen belül külön részletezzük az FDM 3D nyomtatókat, azok müködését. Célul tüztük ki, hogy egy ANET A8 típusú nyomtató elemzésével is foglalkozunk, meghatározva annak hibáit, valamint azokat kijavitva egy jobb müszaki paraméterekkel rendelkezö eszközt hozva létre.
\end{abstract}

Kulcsszavak: 3D nyomtató, FDM, tervezés

\section{Abstract}

This article is about the development, construction and operation of a prototyping technology. FDM $3 D$ printers' functioning are analysed in detail. The aim of the research is to examine an older printer called Anet A8 and, learned from its disadvantages, to design a new device with more beneficial parameters.

Keywords: $3 D$ printer, FDM, designing

\section{Bevezetés}

A gyorsprototípus gyártó technológiák, a CNC elöretörése, a 3D-s nyomtató eljárások elterjedése gyökeresen megváltoztatta az utóbbi évtizedekben a gyártásról alkotott elképzelésünket. 2019-ben egy Tudományos Diákköri Dolgozat keretén belül már szót ejtettünk gyorsprototípus gyártó eszközök egy konkrét fajtájáról, annak kialakulásáról, felépítéséről, müködéséről, valamint tervbe vettük egy új berendezés megtervezését is. Ez a gép az FDM 3D nyomtatók csoportjába tartozik. A mérnöki tudomány ezen ágával kapcsolatban rengeteg anyagot és információt találhatunk különböző online felületeken. Bár ez egy kényelmes tanulási mód, az időt akkor is bele kell fektetni. Ez esetünkben több évig is eltartott. Körülbelül egy év után juthatunk el oda, hogy legyen kellő ismeret alap az első 3D nyomtató megvásárlásához. Javasolt először egy olcsóbb kategóriájú eszközt beszerezni. Ez elég sok kihívást, és ezzel tapasztalatszerzés lehetőségét jelentheti a viszonylag rossz minőségü alkatrészek és rosszul kivitelezett megoldások miatt. Ezeket a gépeket nem ritkán önmagunknak kell összeépíteni, ami körülbelül 6-8 órát vesz igénybe. A nyomtató megépítése, valamint a használatának elkezdése lehetőséget teremt arra, hogy kiismerjük annak müködését. Erre szintén legalább egy évet érdemes fordítani, amikorra már úgy vélhetjük, hogy a készülék hibáit, annak okait és következményeit már 
megértettük. Fontos, hogy felismerjük azokat a hibákat vagy tulajdonságokat, amiket a nyomtató nem saját hibájából, hanem a saját beállításaink miatt produkál. Mindezek után elkezdhetjük ezen nyomtató elemzését, fejlesztését, vagy akár teljes újratervezését.

\section{3D nyomtatás kialakulása}

1860-ban egy francia művész, François Willème létrehozott egy eljárást, amellyel a szükséges információt oly módon mentette el, hogy egy kör alakú szoba közepére helyezte a mintadarabot, majd 24 egyenletes távolságban lévő pozícióból fényképet készített róla. A fényképek előhívása után egy pantográf anyagleválasztó eszközzel a munkadarabot minden oldalról a képek mintájára megfaragta.

J.E. Blanther 1892-ben létrehozott egy eljárást topográfiai térképek készítéséhez. Ebben az eljárásban viasz lapokat vágott ki megfelelő alakra és ragasztotta egymáshoz őket egy olyan térkép létrehozásához, amelyen arányos szintkülönbségek kézzel fogható formában jelentek meg. Papírt ragasztva ennek negatív mintájára sokszorosítani is tudta öket.

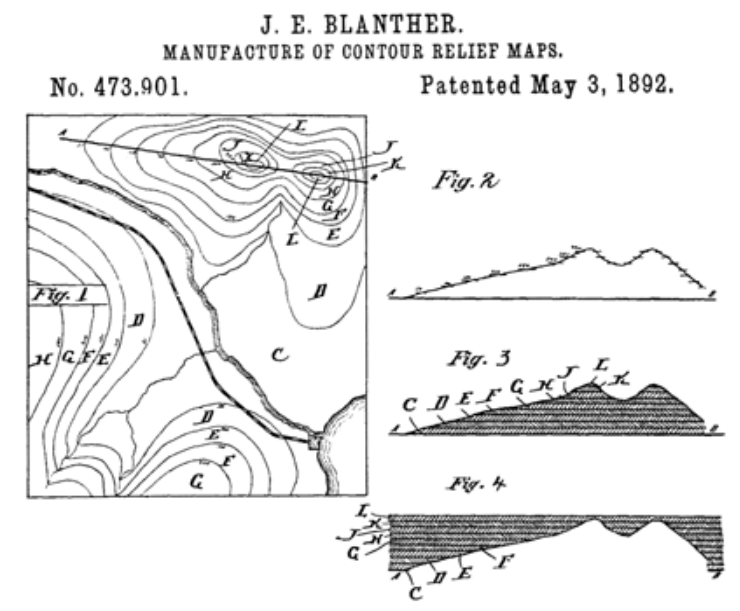

1.ábra. Topográfiai térkép [5]

1984-ben Charles “Chuck” Hull feltalálta a „stereolithography”-t, ez a technológia képes volt folyékony alapanyagból UV fény segítségével szilárd testet létrehozni. Akkoriban még bútorok bevonatát képezték ezzel az eljárással, de ő rájött, hogy ezzel a módszerrel több réteget létrehozva szilárd testet lehet alkotni. 1988-ra eladta első 3D nyomtatóját.

1989-ben S. Scott Crump létrehozott egy másik módszert, ahol szilárd alapanyag megolvasztásával készíthetett alkatrészeket. Ez a módszer volt a ma ismert FFF vagy FDM nyomtatás alapja.

\section{FDM/FFF nyomtatás}

Az FDM (Fused Deposition Modeling), vagy más néven az FFF (Fused Filament Fabrication) nyomtatásnál a felhasznált alapanyag minden esetben valamilyen müanyag. Ennél a technológiánál az alapanyag huzal (filament) formájában kerül felhasználásra. A filament adagolása az extruder motor által történik meghatározott sebességgel. A filamentet egy hevített fém fúvóka alakú nyomtatófejbe (nozzle) préseli a gép, ami a hő hatására megolvad. Az olvadékot rétegenként egymásra helyezve jön létre az alkatrész. A nyomtatás során a gép téglalap keresztmetszetü sávokat nyomtat. Ezen sávok 
magasságát a rétegenkénti $Z$ emelkedés határozza meg, a szélességét pedig a nyomtatófej furata. Általános aranyszabály, hogy a magasság és szélesség aránya nem lehet nagyobb, mint 0,5 . Ha az arányszám meghaladja a javasolt értéket, a rétegek közötti kötőerő rendkívüli mértékben romlik.

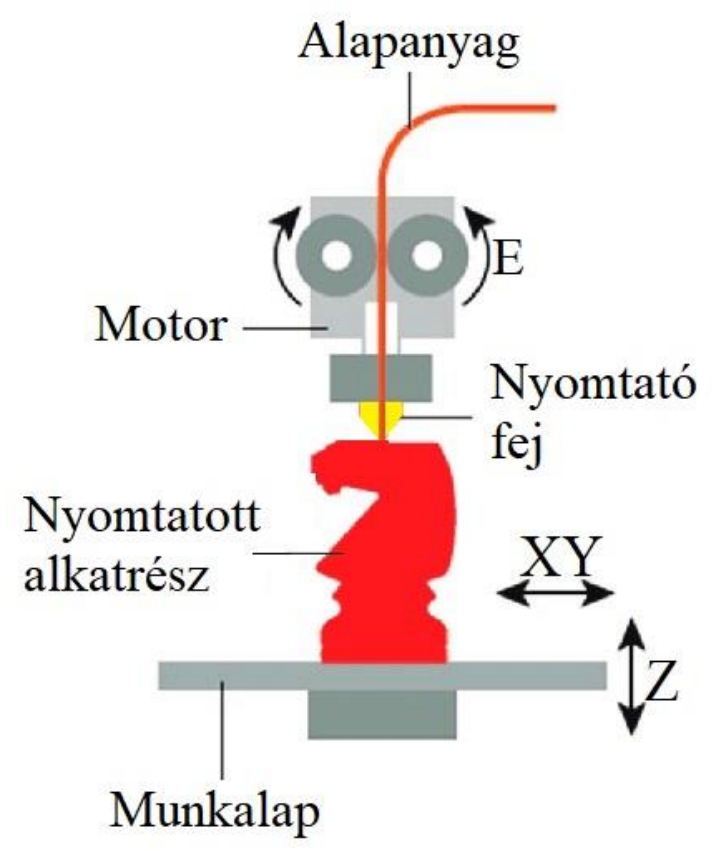

2.ábra. FDM technológia [6]

\section{Vázszerkezet újratervezése}

A vázszerkezet újratervezéséhez a legfontosabb lépés a szerkezet anyagának megválasztása. Fontos megvizsgálni azon szempontokat, amiket figyelembe kell venni a szerkezet újragondolásánál. Ezen szempontok a következők:

- megfelelő szerkezeti merevség;

- $\quad$ kis tömeg;

- $\quad$ alacsony árfekvés;

- $\quad$ könnyü szerelhetöség;

- $\quad$ egyszerủ megmunkálás.

Elsősorban az akril váz áttervezésére lenne szükség. Meglévő tapasztalatokból kiindulva a merevség számottevő növelése csak jelentős mennyiségű akril felhasználásával lenne kivitelezhető. Másrészt az akril megmunkálásához a lézervágó berendezés bérlése igen költséges lenne. Ezenkívül a hőtágulás okozta problémák ezzel még nem oldódnának meg.

A második javaslat a hegesztett zártszelvényböl való építkezés. Sajnos ez viszonylag nagy tömeggel rendelkezik. Szerelhetősége kimondottan bonyolult, mivel hordozza a hegesztési technológia minden nehézségét. Előnye azonban, hogy olcsó és nagy merevséget biztosít. Pontossága azonban kérdéses. 
Harmadik lehetőség az alumínium profil. Ez minden szempontból megfelelő választás. A szükséges szerkezeti merevséget könnyen elérhetjük. Tömege megfelelően kicsi, az ára megfizethetö. Szerelhetőség szempontjából talán a legkedvezőbb választás. Számtalan cég gyárt hozzá kötőelemeket, amelyek segítségével csavarkötéssel gyorsan és egyszerüen építhetjük fel a kívánt szerkezeteket. Megmunkálása egyszerü, hiszen a kötőelemek könnyen csatlakoztathatók a profilhoz, és csupán a méretre vágással kell foglalkozni. Manapság az alumínium profilokkal foglalkozó cégek kérésre méretre vágva szállítják az adott elemeket. A fellelhető fontosabb és megbízhatóbb cégek listája:

- Bosch;

- Lipro;

- Item;

- Isel;

- Maytech;

- Egyéb olcsóbb, de kompatibilis profilok.

Mivel esetünkben a költségvetés nagyon szükre szabott, így a legolcsóbb megoldást kellett választani. Problémát jelenthet a fejlesztés során a vázszerkezetet illetően, hogy a jó minőségü, mérethelyesen legyártott összekötő elemek is igen költségesek lehetnek.

\section{Bowden extruder kialakítása}

Az Anet A8 típusú 3D-s nyomtató esetében a filament adagolásáért felelös léptetőmotor a vízszintes tengelyen (Y irányú szánon) helyezkedik el. A nagy sebességü mozgás során ezt a viszonylag jelentős tömeget a végállásokban nagy gyorsulások, illetve lassulások érik, növelve a vázszerkezetet terhelö erőket. Másrészt a motor közvetlen kapcsolatban áll a nyomtatófejjel, így a motor rezgései átmásolódnak a munkadarabra. Ez a gyártott darab felületi minőségének romlását okozza, amit „ghosting” jelenségnek nevezünk.

A probléma orvoslására egy megoldás, ha úgynevezett bowden elrendezést használunk. Ennek során a léptetőmotort áthelyezzük a gép egy másik pontjára, és a filamentet egy fix hosszúságú csövön vezetjük a nyomtatófejig. Ebben az esetben a mozgó csőben a filamentnek lesz egy kis játéka, ami a nyomtatás során fellépő köztes idő alatt (amikor a nyomtató nyomtatás nélkül tesz meg utat) történő nem szándékolt extrudálást eredményezhet. Szerencsére ez ellen használhatunk a gcode generálásakor olyan eljárásokat, amelyek következtében a köztes időközökre az extruder motor a filamentet visszább húzza. A megvalósításhoz szükséges néhány kiegészítő alkatrészt tervezni, és a használandó csövet megvásárolni. A tervezés során elöször a függőleges tengely ( $Z$ tengely) szánjára került volna az extruder motor, de később mivel egy ún. „szekunder extruder motor” beszerelése is bekerült az igényjegyzékbe, az egész egységet áthelyeztük a vázszerkezet tetejére.

\section{Munkafelület fejlesztése}

Igen fontos feladat az alkatrész megfelelő rögzítése a munkaasztalon. Erre PLA esetén megfelelő megoldás valamilyen ragasztószalag használata. Ilyenkor a ragasztószalagot a munkaasztalra ragasztjuk, amihez az olvadt müanyag könnyebben tapad. Kapható ezen kívül erre a célra kifejlesztett hőálló fólia is (kapton fólia). Ennek a megoldásnak a hibája, hogy a munkadarab eltávolításakor könnyen sérülhet, így sokszor kell cserélni. Létezik olyan mágneses munkafelület, ami két darabból áll. Az egyik darabot a munkalapra ragasztjuk, a másik hajlékony darab pedig mágneses erővel tapad 
az előzőhöz. Ezt a felületet kimondottan arra fejlesztették ki, hogy a nyomtatott alkatrész jól tapadjon hozzá. A munkadarab eltávolításakor a felső réteget elemeljük az alsótól, és mivel az hajlékony, így az alkatrész könnyen lepattintható róla a felület rongálása nélkül.

\section{Vezérlés fejlesztése}

A nyomtató kezelő felülete egy nyomógombos panel, valamint egy kisebb TFT kijelző. Ez elég kényelmetlen kezelést jelent, így ezt egy érintőképernyős panelre cseréltem. Egy másik kényelmes megoldás lehet egy potenciométerrel és egy nyomógombbal történő vezérlés. Ennek lecseréléséhez új alaplapot is be kellett szerezni. Ezen alaplapok általában Arduino alapú microkontrollerek. Lehet ehelyett microcomputert is alkalmazni. A különbség a kettő között, hogy a microcomputert fejlettebb programozásra fejlesztik ki, tehát egy vezérlő szoftverhez előbb egy azt futtató operációs rendszer programozása is szükséges, amíg a microcontroller csak egy elöre definiált programot futtat újra és újra. Céljaink elérésére elegendő egy microcontroller. A kiválasztott alaplap a MKS GEN L V2.0. Továbbá szükség van léptető motorokhoz használandó IC board-okra. Ehhez A4988as modulokat építünk be.

\section{Többszínü gyomtatás}

A vezérlő panel lehetővé teszi, hogy a szükségesnél egyel több léptető motort vezéreljünk. Ezzel lehetőség nyílik a többféle anyaggal történő nyomtatásra. A fejlesztés megvalósításához egy második extruder motor beszerelése szükséges, valamint a nyomtatófej cseréje. Azonos anyag, de kétféle szín nyomtatásához ez elegendő is lenne, amennyiben egy fejen keresztül történik az anyagok extrudálása. Ilyenkor az egyetlen fellépő probléma, hogy a gcode-ot elóállító programok nagy része még nem képes anyagveszteség nélkül kezelni a két anyagú nyomtatást. Ez a probléma az egyik színről a másikra történő áttéréskor jelenik meg, mivel a korábbi szín valamilyen mértékben még a nyomtatófejben van, amikor a másikkal nyomtatni kezd. Ez elmosódást eredményez. A szoftverek megoldása manapság egy ún. „anyag kiengedő” alkatrész nyomtatása. Ilyenkor minden színváltáskor egy később fel nem használandó alkatrészt nyomtat a gép, így kitisztítva a nyomtatófejet. Ez nagyon sok elpazarolt alapanyagot és fölösleges munkát, többletidőt jelent. A 3. ábra egy ilyen nyomtatófej hármas kombinációjának vonalrajza.

Ez a probléma elkerülhető oly módon, hogy két nyomtatófejet használunk. A nyomtatófejek egyszerre mozognak, és a software tudatában van a fejek egymáshoz viszonyított térbeli helyzetének. Ilyenkor megoldható, hogy a két nyomtatófej különböző hömérsékleten legyen, így különböző anyagok is nyomtathatók vele. Ezzel a technológiával olyan alátámasztási anyag is nyomtatható, amit később oldószerrel vagy akár vízzel is eltávolíthatunk, vagy akár részben merev, részben gumiszerü anyagokat kombinálva is alkalmazhatunk egy alkatrészen belül. 


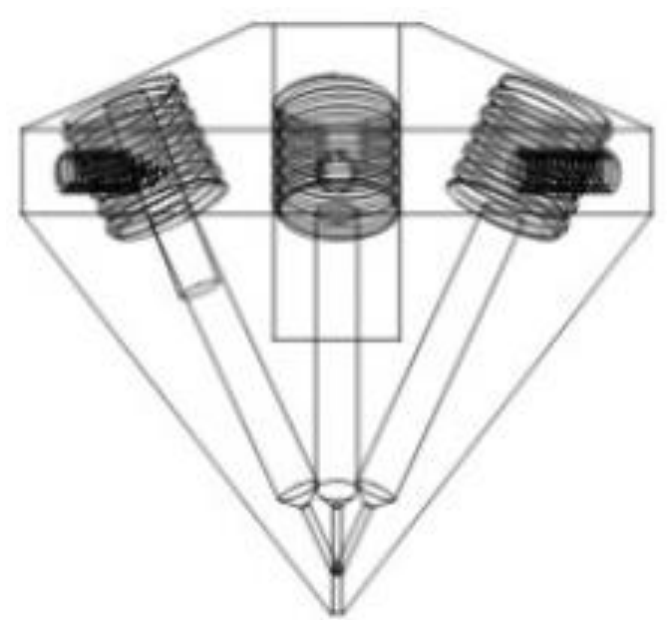

3.ábra. Három utas nyomtatófej [7]

\section{CAD modell készítése}

A CAD modell elkészítéséhez a Solidworks programot használtuk. A gép megépítéséhez sok olyan alkatrészt is kellett tervezni, ami kereskedelmi forgalomban nem kapható. Ezek általában összekötő elemek, és 3D nyomtatással készültek. Természetesen, ha valamikor a gép kereskedelmi forgalomban való árusítását terveznénk, célszerü lenne ezeket az elemeket fröccsöntéssel készíteni. A számítógép számára nehezen kezelhető, vagy a tervezés szempontjából fölösleges elemek megrajzolásától eltekintettünk. Ilyenek például a vezetékek, vagy a vezérlő elektronika és a fogazott szíjak.

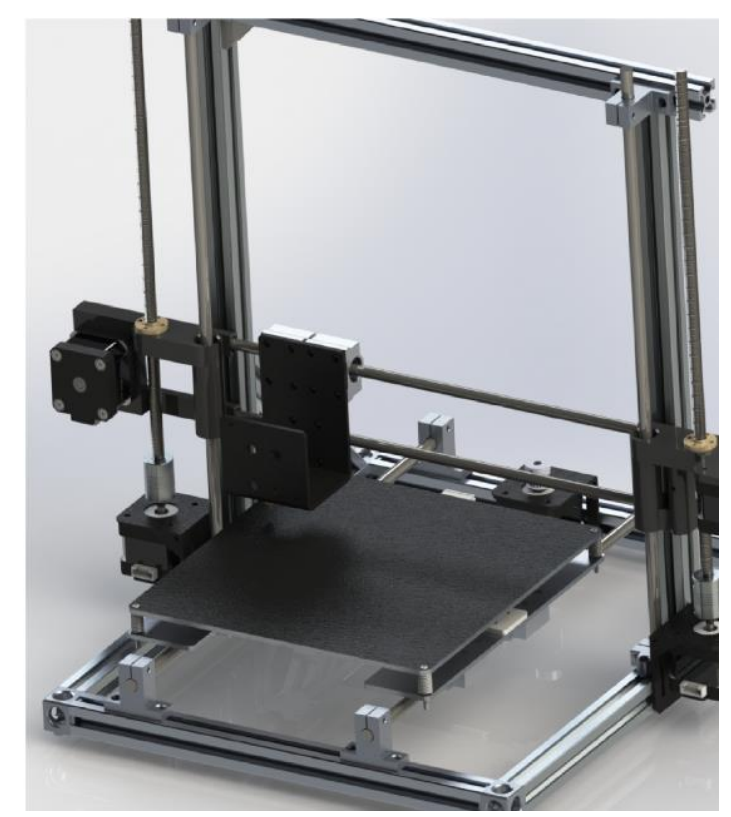

4.ábra. CAD modell 


\section{Köszönetnyilvánítás}

A cikkben ismertetett kutató munka az EFOP-3.6.1-16-2016-00011 jelü „Fiatalodó és Megújuló Egyetem - Innovatív Tudásváros - a Miskolci Egyetem intelligens szakosodást szolgáló intézményi fejlesztése" projekt részeként - a Széchenyi 2020 keretében - az Európai Unió támogatásával, az Európai Szociális Alap társfinanszírozásával valósul meg.

\section{Irodalom}

[1] Makó, I., Zsiga, Z.: Forgácsolástechnológia számítógépes tervezése II. NC/CNC programozói ismeretek, számítógéppel segített CNC programozás, Szakmérnöki jegyzet

[2] Fülöp, Gy., Horváth, M., Kodácsy, J.: Gyors prototípusgyártás marással, Fiatal Müszakiak Tudományos Ülésszaka, Kolozsvár, 2003. március 21-22.

[3] Kugler, G., Bihari, Z.: CNC vezérelt lézer gravírozó komplex tervezése, A jövő mérnökeinek prezentációi 2018, (Szerk: Bihari, Zoltán), ISBN 978-963-358-185-8., Miskolc, 2019.

[4] Sarka, F., Szente, J.: Interaktivitás a tervezésben és a prototípusgyártásban. Nemzeti Tankönyvkiadó. (Sanoma company), Budapest, 2009.

[5] https://link.springer.com/chapter/10.1007/978-3-319-31686-4_5

[6] https://www.researchgate.net/figure/Ink-based-3D-printing-method-a-schematic-of-FDMmethod-b-schematic-of-DIW-method-46_fig2_328201272

[7] https://www.amazon.com/Extruder-Nozzle-1-75mm-Filament-Printer/dp/B07QFLZ72S 